\title{
Development of Java Tea based Functional Drink: Scale-up Formula Optimization based on the Sensory and Antioxidant Properties
}

\author{
C. H. Wijaya ${ }^{1,2^{*}}$, N. Sutisna ${ }^{1}$, B. Nurtama ${ }^{2}$, T. Muhandri ${ }^{2}$, S. Indariani ${ }^{1}$ \\ ${ }^{1}$ Tropical Biopharmaca Research Center, Bogor Agricultural University, Bogor, 16128, Indonesia. \\ ${ }^{2}$ Department of Food Science and Technology, Bogor Agricultural University, Bogor, 16151, Indonesia.
}

\section{ARTICLE INFO \\ Article history: \\ Received on: 10/12/2017 \\ Accepted on: 15/03/2018 \\ Available online: 30/09/2018}

\section{Key words:}

formula optimization,

functional drink, Java tea, product development.

\begin{abstract}
A Java tea-based functional drink was modified by using simplicia extracts rather than fresh ingredients to facilitate mass production. However, the modification can impact a product's nutraceutical efficacy as well as its sensory properties. This study aimed to optimize the formula for the modified Java tea-based functional drink in terms of both maximum antioxidant properties (efficacy) and sensory properties (color, taste, and aroma). Formula optimization was performed by response surface methodology (RSM) using Design Expert ${ } 7$ software. Java tea extract (JE), sappan wood extract (SE), ginger extract (GE), and lime extract (LE) contents were identified as important factors for optimization because of the antioxidant and desirable sensory properties of these ingredients. Sensory evaluation was conducted using the balanced incomplete block design (BIBD) method. Ultimately, a Java tea-based functional drink was successfully formulated from simplicia extracts with optimum sensory and antioxidant properties. The antioxidant activity of the optimum formula was $335.69 \pm 48.30 \mathrm{ppm}$ ascorbic acid equivalent antioxidant capacity and the sensory acceptance scores (on a scale of 1-7) were 5.6 for color, 5.8 for taste, 5.2 for aroma, and 5.2 for overall attributes (corresponding to 'like slightly' to 'like moderately'). Simplicia extracts in appropriate combinations can be used instead of fresh ingredients for the large-scale production of a Java tea-based functional drink while maintaining efficacy and palatability.
\end{abstract}

\section{INTRODUCTION}

Functional foods believed to promote general health and reduce the risk of diseases are becoming increasingly popular, including various herbal drinks. Many of these herbal drinks are produced from traditional medicinal ingredients such as Java tea. Research on Java tea-based functional drinks has shown promising health benefits such as antihyperglycemic activity (Indariani et al., 2014). Furthermore, these drinks are rich in antioxidants (Wijaya et al., 2010). A Java tea-based functional drink prepared using fresh ingredients was reported to possess 532.307-726.818 ppm ascorbic acid equivalent antioxidant capacity (AEAC) (Wijaya et al., 2007; Wijaya et al., 2011).

Pilot production of a Java tea-based functional drink

${ }^{*}$ Corresponding Author

C. H. Wijaya, Tropical Biopharmaca Research Center, Kampus IPB

Taman Kencana, Jalan Taman Kencana No. 3.

E-mail:hazemi@indo.net.id using fresh ingredients has been conducted at both 10-L (Wazirroh et al., 2013) and 100-L scales (Wijaya et al., 2014), and both trials yielded promising results for eventual commercialization. However, utilization of fresh ingredients is often limited by availability and short shelf-life. To produce this tea on an industrial scale, extracts of Java tea, sappan wood, ginger, and curcuma were modified using simplicia instead of fresh ingredients.

Modification of extraction processes and ingredients may impact the functional efficacy of the product as well as its sensory properties. Therefore, this study aimed to optimize the formula of a Java tea-based functional drink made from simplicia extracts according to sensory and antioxidant properties.

\section{MATERIAL AND METHODS}

\section{Plant Materials}

Java tea (Orthosiphon aristatus (Blume) Miq., specimen No. BMK0076042016), sappan wood (Caesalpinia sappan L, specimen No. BMK0120092016), ginger (Zingiber 
officinale Roscoe, specimen No. BMK0043052015), lime (Citrus aurantifolia (Christm.) Swingle, specimen No. BMK0202092016), lemon (Citrus limon (L.) Osbeck, specimen No. BMK0201092016), kaffir lime (Citrus histrix DC, specimen No. BMK0189092016), and curcuma (Curcuma xanthorrhiza Roxb, specimen No. BMK0042072014) were identified and deposited at the Tropical Biopharmaca Research Center, Bogor Agricultural University, Bogor, Indonesia.

\section{Chemical materials}

Ascorbic acid, 1,1-diphenyl-2-picrylhydrazyl (DPPH), methanol, ethanol, dipotassium hydrogen phosphate, potassium dihydrogen phosphate, sodium carbonate, sodium acetate trihydrate, and acetic acid (glacial) 100\% were purchased from Sigma-Aldrich. Acarbose (Glucobay) was purchased from a local pharmacy. $\alpha$-Glucosidase sourced from Bacillus stearothermophilus (G3651) and 4-nitrophenyl $\alpha$-D-glucopyranoside (PNPG) N1377 were purchased from Sigma-Aldrich.

\section{Preparation of extracts}

Extract of java tea, sappan wood, ginger, lime, lemon, kaffir lime, and curcuma were produced by selected toll manufacturing. Java tea, sappan wood, ginger, and curcuma were then extracted in boiling water and filtered through membranes under pressure. Lime, lemon, and kaffir lime were extracted from fresh ingredients using a screw pressing machine. All the collected extracts were pasteurized to meet microbial requirements and stored at $10^{\circ} \mathrm{C}$ or colder.

\section{Extract characterization}

All the extracts were analyzed for physical, chemical, and microbiological characteristics. Physical characteristics examined included appearance, $\mathrm{pH}$, specific gravity, and solubility. Chemical characteristics examined were heavy metal content and antioxidant activity. The total plate counts of fungi, E. coli, $S$. aureus, Salmonella sp., and $P$. aeruginosa were also examined as microbial characteristics.

\section{Formula optimization}

The optimal formula was determined by response surface methodology (RSM) using mixture design and analyzed by Design Expert $\mathbb{R}$ 7. The concentrations of Java tea extract (JE), sappan wood extract (SE), ginger extract (GE), and lime extract (LE) were selected as variables because of their antioxidant and sensory properties. The constraints of each factor were previously established during preliminary trials. The Java tea-based functional drink was then formulated by adding fixed concentrations of curcuma extract, lemon extract, kaffir lime extract, sucrose, aceculfame-K, sucralose, flavor enhancer, and xathan gum in water. Twenty-one experimental formulations were prepared to determine the formula with optimal antioxidant activity and sensory properties. Analysis of variance (ANOVA) was used to

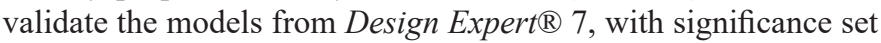
at $\mathrm{p}<0.05$. After obtaining the optimum formula, we conducted verification analyses and measured antihyperglycemic activity by the $\alpha$-glucosidase inhibition method.

\section{Analysis of antioxidant activity}

Antioxidant activity was measured as described by Kubo et al. (2002) and Molyneux (2004) with minor modifications. The analysis was performed using an Elisa reader (Biotek) using ascorbic acid as the standard. The results are expressed as ppm AEAC. Each measurement was performed in triplicate.

\section{Sensory evaluation}

Sensory evaluation was conducted according to the balanced incomplete block design (BIBD) method described by Cochran and Cox (1957). In this study, the BIBD was arranged for 21 numbers of block $(b), 5$ numbers of units per block $(k), 5$ numbers of replication $(r)$, and 21 numbers of treatments $(t)$. By following this design, the efficiency factor was 0.84 (high numbers indicate greater precision).

Hedonic ratings were performed by 21 screened panelists who evaluated taste, color, aroma, and overall attributes of the Java tea-based drink on a 7-point scale: (1) dislike extremely, (2) dislike moderately, (3) dislike slightly, (4) neither like nor dislike (neutral), (5) like slightly, (6) like moderately, (7) like extremely. Responses were then analyzed by Design Expert $(\mathbb{R} 7$ to determine the optimum beverage formula.

\section{Analysis of antihyperglycemic activity}

Antihyperglycemic activity was measured using the $\alpha$-glucosidase inhibition method as described by Mayur et al. (2010) with minor modifications. The analysis was performed using an Elisa reader (Biotek). Briefly, a beverage sample (10 $\mu \mathrm{L}$ ) was mixed with $50 \mu \mathrm{L}$ of $0.1 \mathrm{M}$ phosphate buffer ( $\mathrm{pH} 7.0$ ), $25 \mu \mathrm{L}$ of $0.5 \mathrm{mM} 4$-nitrophenyl $\alpha$-D-glucopyranoside, and $25 \mu \mathrm{L}$ of $\alpha$-glucosidase solution $(0.04 \mathrm{Unit} / \mathrm{mL})$ in microplate wells. The mixture was incubated at $37^{\circ} \mathrm{C}$ for $30 \mathrm{~min}$ and the reaction terminated by adding $100 \mu \mathrm{L}$ of $0.2 \mathrm{M}$ sodium carbonate solution. Blanks with enzymes replaced by buffer were prepared to correct background absorbance. Negative controls with sample replaced by methanol were also prepared. Positive controls contained Acarbose (10 ppm). Each measurement was performed in triplicate.

\section{RESULT AND DISCUSSION}

\section{Extract characterization}

Characteristics of extracts are presented in Table 1. Characterization of simplicia extracts was useful for determining extract ingredients. Extract characteristics met the standard requirements of PerKa BPOM No. 12 (2014) from The Indonesia National Agency of Drug and Food Control.

\section{Mixture design analysis of Java tea-based functional drink}

Five responses (antioxidant activity, color, taste, aroma and overall attributes) for formula optimization of the Java teabased functional drink were analyzed by Design Expert ${ }^{\circledR} 7$. The Responses for each formula are presented in Table 2.

\section{Effect of formula optimization on antioxidant activity}

The antioxidant activity of the 21 experimental Java tea-based drink formulas varied between 116 and 313 ppm AEAC (Table 3). The polynomial equation of antioxidant activity revealed interaction effects among ingredients. Based on D-optimal mixture design analysis, a quadratic model of antioxidant activity was 
derived that fit the data with statistical significance $\left(\mathrm{p}<0.05, \mathrm{R}^{2}\right.$ $=0.8202$ ). The response surface $3 \mathrm{D}$ graph of antioxidant activity

is shown in Figure 1. The mathematical models of each individual response are presented in Table 3.

Table 1: Characteristics of extracts from selected toll manufacturing.

\begin{tabular}{|c|c|c|c|c|c|c|c|}
\hline Extract Name & Java tea & Sappan Wood & Ginger & Curcuma & Kaffir lime & Lime & Lemon \\
\hline Physical appearance & $\begin{array}{c}\text { Brown to dark } \\
\text { brown liquid }\end{array}$ & $\begin{array}{l}\text { Reddish brown } \\
\text { liquid }\end{array}$ & $\begin{array}{c}\text { Brown to dark } \\
\text { brown liquid }\end{array}$ & $\begin{array}{c}\text { Yellowish brown } \\
\text { liquid }\end{array}$ & $\begin{array}{l}\text { Yellowish white to } \\
\text { yellow liquid }\end{array}$ & Light yellow liquid & Light yellow liquid \\
\hline $\mathrm{pH}$ & 6.66 & 6.24 & 6.86 & 6.43 & 3.00 & 2.87 & 3.01 \\
\hline Specific gravity $(\mathrm{g} / \mathrm{mL})$ & 1.0011 & 1.0017 & 1.0168 & 1.0019 & 1.0372 & 1.0359 & 1.0287 \\
\hline \multicolumn{8}{|l|}{ Heavy metal } \\
\hline $\mathrm{Pb}(\leq 10 \mathrm{mg} / \mathrm{kg})$ & conform & conform & conform & conform & conform & conform & conform \\
\hline $\mathrm{Cd}(\leq 0.3 \mathrm{mg} / \mathrm{kg})$ & conform & conform & conform & conform & conform & conform & conform \\
\hline As $(\leq 5 \mathrm{mg} / \mathrm{kg})$ & conform & conform & conform & conform & conform & conform & conform \\
\hline $\mathrm{Hg}(\leq 0.5 \mathrm{mg} / \mathrm{kg})$ & conform & conform & conform & conform & conform & conform & conform \\
\hline \multicolumn{8}{|l|}{ Microbiology } \\
\hline TPC (max. $10^{4} \mathrm{CFU} / \mathrm{g}$ ) & $10 \mathrm{cfu} / \mathrm{g}$ & $70 \mathrm{cfu} / \mathrm{g}$ & $90 \mathrm{cfu} / \mathrm{g}$ & $50 \mathrm{cfu} / \mathrm{g}$ & $320 \mathrm{cfu} / \mathrm{g}$ & $10 \mathrm{cfu} / \mathrm{g}$ & $20 \mathrm{cfu} / \mathrm{g}$ \\
\hline Fungi (max. $10^{3} \mathrm{CFU} / \mathrm{g}$ ) & $<10 \mathrm{cfu} / \mathrm{g}$ & $<10 \mathrm{cfu} / \mathrm{g}$ & $<10 \mathrm{cfu} / \mathrm{g}$ & $<10 \mathrm{cfu} / \mathrm{g}$ & $<10 \mathrm{cfu} / \mathrm{g}$ & $<10 \mathrm{cfu} / \mathrm{g}$ & $<10 \mathrm{cfu} / \mathrm{g}$ \\
\hline E. coli (negative) & negative & negative & negative & negative & negative & negative & negative \\
\hline S. aureus (negative) & negative & negative & negative & negative & negative & negative & negative \\
\hline Salmonella sp. (negative) & negative & negative & negative & negative & negative & negative & negative \\
\hline P. Aeruginosa (negative) & negative & negative & negative & negative & negative & negative & negative \\
\hline Antioxidant (ppm AEAC) & 380.44 & 952.47 & 480.83 & 297.30 & 953.24 & 226.42 & 335.23 \\
\hline Solubility in water & conform & conform & conform & conform & conform & conform & conform \\
\hline
\end{tabular}

Table 2: Experimental design and responses for Java tea-based functional drink optimization.

\begin{tabular}{|c|c|c|c|c|c|c|c|c|c|}
\hline \multirow{3}{*}{ Treatments } & \multicolumn{4}{|c|}{ Factors $(\%)$} & \multicolumn{5}{|c|}{ Responses } \\
\hline & \multirow{2}{*}{ JE } & \multirow{2}{*}{ GE } & \multirow{2}{*}{ SE } & \multirow{2}{*}{ LE } & \multirow{2}{*}{ Antioxidant Activity (ppm AEAC) } & \multicolumn{4}{|c|}{ Sensory Properties } \\
\hline & & & & & & Color & Taste & Aroma & Overall \\
\hline run 1 & $*$ & $*$ & $*$ & $*$ & 239.13 & 4.8 & 4.4 & 5.4 & 4.6 \\
\hline run 2 & $*$ & $*$ & $*$ & $*$ & 131.40 & 4.8 & 4.4 & 4.8 & 4.6 \\
\hline run 3 & $*$ & $*$ & $*$ & $*$ & 278.26 & 5.6 & 4.6 & 5 & 5 \\
\hline run 4 & * & $*$ & $*$ & $*$ & 157.49 & 4.8 & 5.4 & 4.6 & 4.8 \\
\hline run 5 & $*$ & $*$ & $*$ & $*$ & 116.91 & 5.2 & 5.2 & 5.4 & 5.4 \\
\hline run 6 & $*$ & $*$ & $*$ & $*$ & 243.96 & 6 & 4.2 & 5 & 4.8 \\
\hline run 7 & $*$ & $*$ & $*$ & $*$ & 177.78 & 5.8 & 5.2 & 5.6 & 5.6 \\
\hline run 8 & $*$ & $*$ & $*$ & $*$ & 265.22 & 5 & 4.6 & 4.8 & 4.6 \\
\hline run 9 & $*$ & $*$ & $*$ & $*$ & 213.53 & 5 & 5.2 & 4.8 & 5.2 \\
\hline run 10 & $*$ & $*$ & $*$ & $*$ & 199.03 & 5.8 & 4.8 & 5 & 5 \\
\hline run 11 & $*$ & $*$ & $*$ & $*$ & 242.03 & 5.2 & 3.8 & 5 & 4.2 \\
\hline run 12 & $*$ & $*$ & $*$ & $*$ & 157.00 & 4 & 5.6 & 4.6 & 5 \\
\hline run 13 & $*$ & $*$ & $*$ & $*$ & 220.77 & 3.8 & 5.2 & 5.4 & 4.8 \\
\hline run 14 & $*$ & $*$ & $*$ & $*$ & 251.69 & 4.6 & 5.2 & 4.6 & 5 \\
\hline run 15 & $*$ & $*$ & $*$ & $*$ & 313.04 & 5.4 & 5.4 & 5.6 & 5.6 \\
\hline run 16 & $*$ & $*$ & $*$ & $*$ & 227.05 & 4 & 5.2 & 5.2 & 5.4 \\
\hline run 17 & $*$ & $*$ & $*$ & $*$ & 255.56 & 4.6 & 5 & 5.2 & 5.2 \\
\hline run 18 & $*$ & $*$ & $*$ & $*$ & 216.43 & 4.6 & 5 & 5.2 & 5.2 \\
\hline run 19 & $*$ & $*$ & $*$ & $*$ & 206.28 & 5.2 & 5 & 4.6 & 5 \\
\hline run 20 & $*$ & $*$ & $*$ & $*$ & 265.70 & 4.6 & 5.4 & 5.2 & 4.6 \\
\hline run 21 & $*$ & $*$ & $*$ & $*$ & 131.88 & 3.2 & 3.4 & 4.6 & 3.4 \\
\hline
\end{tabular}

$\mathrm{JE}=$ Java tea extract, $\mathrm{GE}=$ Ginger extract, $\mathrm{SE}=$ Sappan wood extract, $\mathrm{LE}=$ Lemon extract, AO = Antioxidant activity. 
Design-Expert 8 Software

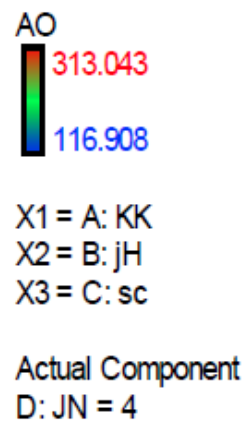

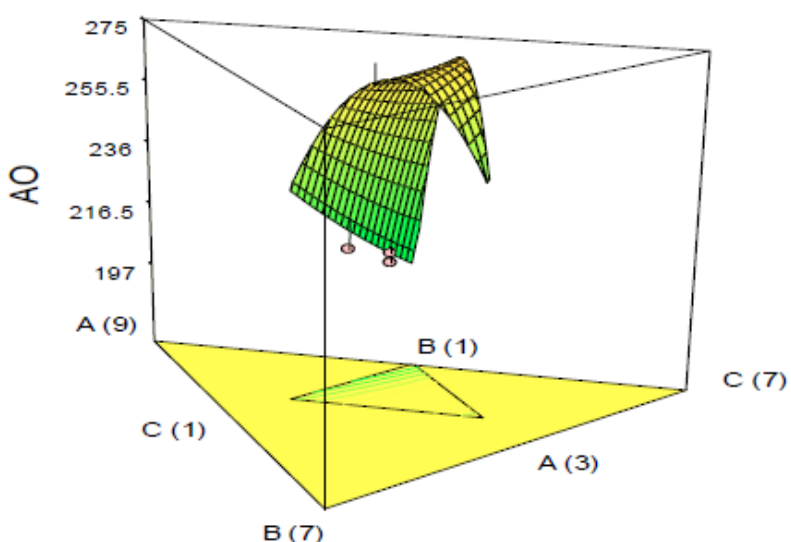

Fig. 1: Three-dimensional graph of antioxidant activity response.

Table 3: Mathematical models for each individual response.

\begin{tabular}{|c|c|c|c|c|c|c|c|}
\hline Responses & Models & Polynomial equation & R-squared & $\begin{array}{l}\text { Predicted } \\
\text { R-squared }\end{array}$ & $\begin{array}{l}\text { Adjusted } \\
\text { R-squared }\end{array}$ & $\begin{array}{l}\text { Adequate } \\
\text { precision }\end{array}$ & $\begin{array}{l}\text { Lack } \\
\text { of fit }\end{array}$ \\
\hline Antioxidant activity & Quadratic & $\begin{array}{c}-116.23 \mathrm{JE}-190.31 \mathrm{GE}-134.63 \mathrm{SE}-167.23 \mathrm{LE}+47.46 \mathrm{JE} * \mathrm{GE}+30.14 \mathrm{JE} * \mathrm{SE}+ \\
\text { 18.3JE*LE1.50GE*SE+36.92GE*LE+ } \\
\text { 44.61SE*LE }\end{array}$ & 0.8202 & 0.0804 & 0.6743 & 8.058 & Sig \\
\hline Taste & Mean & - & - & - & - & - & - \\
\hline Color & Mean & - & - & - & - & - & - \\
\hline Aroma & Mean & - & - & - & - & - & - \\
\hline Overall & Mean & - & - & - & - & - & - \\
\hline
\end{tabular}

\section{Effect of formula optimization on sensory evaluations}

In contrast to drugs and supplements, sensory characteristics are critical factors determining public acceptance of functional foods and drinks. In this study, sensory evaluation of the Java tea-based functional drink was performed by screened panelists. Evaluation followed a balanced incomplete block design. Color, taste, aroma, and overall attributes were used as responses for formula optimization (Table 2). All sensory attributes were fitted with a mean model (Table 3) indicating that color, taste, aroma, and overall attributes were not significantly influenced by the component factors.

\section{Formula optimization}

To achieve the optimum formula, each individual factor and response was ranked according to importance (Table 4). Antioxidant activity, taste, and color were considered to be of maximum importance $(5,+++++)$ because of the major influences of these factors on both functionality and sensorial acceptance, while the other factors and responses were considered to be of intermediate importance, ranging from $3(+++)$ to $4(++++)$.

Based on RSM analysis, the optimal formula for a Java tea-based functional drink produced from simplicia extracts was determined according to antioxidant and sensory properties. The optimal formula has a desirability value of 0.85 (Table 5), a predicted antioxidant content of $277.23 \mathrm{ppm}$ AEAC, and predicted sensory acceptance scores of 4.87 for taste, 4.86 for color, 5.03 for aroma, and 4.90 for overall attributes. These ratings range from "neither like nor dislike" to "like slightly" (Table 6).
Table 4: Importance criteria for Java tea-based functional drink optimization.

\begin{tabular}{ccccc}
\hline Component/Response & Goal & Minimum & Maximum & Importance \\
\hline $\mathrm{JE}$ & in range & 20 & 40 & $3(+++)$ \\
$\mathrm{GE}$ & in range & 6.8 & 20 & $3(+++)$ \\
$\mathrm{SE}$ & in range & 6.8 & 26.7 & $3(+++)$ \\
$\mathrm{LE}$ & in range & 15.3 & 33.3 & $3(+++)$ \\
Antioxidant activity & maximize & 116.908 & 313.043 & $5(+++++)$ \\
(ppm AEAC) & in range & 3.2 & 6 & $5(+++++)$ \\
Color & in range & 4.6 & 5.6 & $4(++++)$ \\
Aroma & maximize & 3.4 & 5.6 & $5(+++++)$ \\
Taste & in range & 3.4 & 5.6 & $4(++++)$ \\
Overall & & & &
\end{tabular}

\section{Verification}

Results from the prediction formula were compared to actual experimental results for verification (Table 7). The actual antioxidant activity (335.69 \pm 48.30 ppm AEAC) was reasonably close to the predicted value (277.23 ppm AEAC). Thus, as predicted, the utilization of simplicia extracts influenced product efficacy (Table 6). Moreover, the measured antioxidant activity was lower than that of previous pilot-scale production runs using fresh ingredients, where levels of 709 ppm AEAC (Waziiroh et al., 2013) and 910.97 ppm AEAC (Wijaya et al., 2014) were obtained. This decrease in antioxidant activity is likely the result of utilizing simplicia extracts. These results are in accordance with the findings of Herreros et al. (2010) that the effects of heating 
on the antioxidant activities of spices and vegetable products are influenced by the type of raw materials and processing conditions. Reductions in antioxidant activity and phenolic compounds by sterilization were also reported for a herbal drink by Techaratanakrai et al. (2009). The heat exposure involved in simplicia extract production can indeed reduce antioxidant activity, but this drawback is compensated by the ease of industrial production.

Table 5: Suggested optimized formulae.

\begin{tabular}{|c|c|c|c|c|c|c|c|c|c|c|}
\hline No & JE & GE & SE & LE & AO & taste & color & aroma & overall & Desirability \\
\hline$\underline{1}$ & $*$ & $*$ & $*$ & * & $\underline{277.2303}$ & $\underline{4.866667}$ & $\underline{4.857143}$ & $\underline{5.028571}$ & $\underline{4.904762}$ & $\underline{0.852155}$ \\
\hline 2 & $*$ & $*$ & $*$ & * & 273.9374 & 4.866667 & 4.857143 & 5.028571 & 4.904762 & 0.848625 \\
\hline 3 & $*$ & $*$ & $*$ & * & 262.7117 & 4.866667 & 4.857143 & 5.028571 & 4.904762 & 0.836129 \\
\hline 4 & $*$ & $*$ & $*$ & $*$ & 256.5069 & 4.866667 & 4.857143 & 5.028571 & 4.904762 & 0.828888 \\
\hline
\end{tabular}

Table 6: Predicted responses for the optimized formula.

\begin{tabular}{|c|c|c|c|c|c|c|c|}
\hline Responses & Prediction & SE Mean & 95\% CI low & 95\% CI high & SE Pred & 95\% PI low & 95\% PI high \\
\hline $\mathrm{AO}$ & 277.23 & 17.99 & 237.64 & 316.82 & 35.14 & 199.90 & 354.56 \\
\hline Taste & 4.87 & 0.12 & 4.61 & 5.12 & 0.58 & 3.66 & 6.08 \\
\hline Color & 4.86 & 0.15 & 4.54 & 5.18 & 0.72 & 3.35 & 6.36 \\
\hline Aroma & 5.03 & 0.07 & 4.88 & 5.18 & 0.34 & 4.31 & 5.75 \\
\hline Overall & 4.90 & 0.11 & 4.68 & 5.13 & 0.51 & 3.84 & 5.96 \\
\hline
\end{tabular}

Table 7: Comparison of predicted to actual experimental results.

\begin{tabular}{ccc}
\hline Responses & Prediction & Verification \\
\hline Antioxidant activity (ppm AEAC) & 277.23 & $335.69 \pm 48.30$ \\
Taste & 4.87 & 5.8 \\
Color & 4.86 & 5.6 \\
Aroma & 5.03 & 5.2 \\
Overall & 4.90 & 5.2 \\
\hline
\end{tabular}

Although antioxidant activity decreased, the optimized formula for this Java tea-based functional drink prepared using simplicia extracts retains antioxidant activity equivalent to 60-70 $\mathrm{mg}$ of ascorbic acid (vitamin C). According to US Food and Drug Administration (FDA) regulations, products labeled as high in antioxidants must contain $20 \%$ or more of the recommended daily intake of vitamin C (minimum $30 \mathrm{mg}$ ) (FDA, 2017).

Sensory ratings were 5.6 for color, 5.8 for taste, 5.2 for aroma, and 5.2 for overall attributes, corresponding to "like slightly" to "like moderately" on the 7-point scale. These results are within the $95 \%$ prediction interval of the models (Table 6). All parameters (antioxidant activity and sensory attributes) were close to corresponding model predictions, thereby validating the RMS models.

\section{Antihyperglycemic activity of the optimized formula}

The antihyperglycemic activity of the optimum formula as measured by $\alpha$-glucosidase inhibition assay was $31.98 \% \pm$ $0.21 \%$, similar to the $29.91 \%$ measured from a Java tea-based functional drink made from fresh ingredients (Wijaya et al., 2014). Indariani et al. (2014) reported that Java tea-based functional drinks are enriched in phenols and that total phenols are strongly correlated with both antihyperglycemic and antioxidant activities. However, the current study did not reveal such a correlation, as antihyperglycemic activity did not differ between a Java tea-based functional drink made from simplicia extracts and that made from fresh ingredients. However, the fruit extracts used in both formulations (lime, kaffir lime, and lemon) were extracted from fresh ingredients and all are reported to have antihyperglycemic activities (Wijaya et al., 2010; Tadera et al., 2006; Ladaniya, 2008; Kim et al., 2000). The utilization of fresh fruit extracts is therefore expected to maintain the antihyperglycemic activity of Java tea-based functional drinks whether made from simplicia extracts or fresh ingredients.

\section{CONCLUSION}

A Java tea-based functional drink was successfully formulated from simplicia extracts with optimal sensory and antioxidant properties. The antioxidant activity of the optimum formula was $335.69 \pm 48.30 \mathrm{ppm}$ AEAC and the sensory acceptance ratings for color, taste, aroma, and overall attributes (on a 7-point scale) ranged from 5.2 to 5.8. The antihyperglycemic activity of the optimum formula was $31.98 \% \pm 0.21 \%$ as measured by the $\alpha$-glucosidase inhibition method. Thus, simplicia extracts are suitable for the mass production of Java tea-based functional drinks.

\section{ACKNOWLEDGMENT}

This study was financially supported by Riset InovatifProduktif (RISPRO) Komersial Lembaga Pengelola Dana Pendidikan (LPDP), Ministry of Finance of Republic of Indonesia. The authors gratefully acknowledge the technical support of the Tropical Biopharmaca Research Center and Department of Food Science and Technology, Bogor Agricultural University.

\section{REFERENCES}

BPOM. The Indonesia National Agency of Drug and Food Control. 2012. PerKa BPOM No. 12 Tahun 2014 Tentang Persyaratan Mutu Obat Tradisional (Traditional Medicinal quality Requirements). Jakarta, Indonesia: BPOM.

Cochran WG, Cox GM. 1957. Experimental design. New York, USA: John Wiley and Sons, Inc.

Herreros CG, Iniguez MG, Astiasaran I, Ansorena D. Antioxidant 
activity and phenolic content of waters of Borago officinalis L.: influence of plant part and cooking procedure. Ital J Food Sci. 2010; 22(2):156-164.

Indariani $\mathrm{S}$, Wijaya $\mathrm{CH}$, Rahminiwati $\mathrm{M}$, Winarno MW. Antihyperglycemic activity of functional drinks based on Java tea (Orthosiphon aristatus) in streptozotosin induced diabetic mice. Int Food Research J. 2014; 21:349-355.

Kim JS, Kwon CS, Son KH. Inhibition of alpha-glucosidase and amylase by luteolin: a flavonoid. Bioscience, Biotechnology and Biochemistry. 2000; 64(11):2458-2461.

Kubo I, Matsuoka N, Xiao P, Haraguchi H. Antioxidant activity of dodecyl gallate. J Agric Food Chem. 2002; 50:3533-3539.

Ladaniya MS. 2008. Citrus Fruit: Biology, Technology and evaluation. San Diego, USA: Academic Pres.

Mayur B, Sandez S, Shruti S, Sung-Yum S. Antioxidant and alpha-glucosidase inhibitory properties of Carpesium abrotanoides L. J Med Plants Res. 2010; 4(15):1547-1553.

Molyneux P. The use of the stable free radical diphenylpicrylhydrazyl (DPPH) for estimating antioxidant activity. J Sci Tech. 2004; 26(2):211-219.

Tadera K, Minami Y, Takamatsu K, Matsuoka T. Inhibition of á-glucosidase and á-amylase by flavonoids. J Nut Sci Vit. 2006; 52(2):149153.

Techaratanakrai B, Laohasongkram K, Chaiwanichsiri S. Development of a sterilized mixed herbal drink product. Int J Food Eng. 2009; 5(3): Article 8.

U.S. Food and Drug Administration. 2017. CFR - Code Federal of Regulations Title 21 Volume 2. Cite: 21CFR101.54 [ONLINE] Available at: https://www.accessdata.fda.gov/scripts/cdrh/cfdocs/cfcfr/CFRSearch. $\mathrm{cfm} ? \mathrm{fr}=101.54$ [Accessed 25 August 2017].
Waziiroh E, Wijaya CH, Nurtama B. 2013. Optimization of the Pilot Plant Scale Production of Functional Drink Based on Java tea (Orthosiphon aristatus BI. Miq) Extract. Thesis. Sekolah Pascasarjana. Bogor Agricultural University. Bogor (ID).

Wijaya CH, Achmadi SS, Herold, Indariani S. 2007. Formulation and The Processing of Java Tea based functional drink (Orthosiphon aristatus). Patent of Indonesia (ID) 00200700564.

Wijaya CH, Darusman LK, Djauhari PK, Nurtama B, Putri EIK, Heryanto R, Yuliana ND, Heryanto R, Indariani S, Widowati T. 2014. Development of active physiology, production and commercialization of Java Tea based functional drink. Research's report of RISPRO LPDP. Bogor: Bogor Agricultural University.

Wijaya $\mathrm{CH}$, Rahminiwati M, Indariani S, Herold, Kordial N, Afandi A, Lo D. 2011. Formulation of Java Tea based functional drink to Overcome and Prevention of Hyperglycemic. Patent of Indonesia (ID) 00201100914.

Wijaya $\mathrm{CH}$, Rahminiwati M., Chen H, Kordial N, and. Lo D. 2010. In Vitro and Ex Vivo Anti hyperglycemic Activities of Java tea (Orthosiphon aristatus BI. Miq) - based Functional Drink. Proceeding of 15th World Congress of Food Science and Technology. Cape Town: South Africa.

\section{How to cite this article:}

Wijaya CH, Sutisna N, Nurtama B, Muhandri T, Indariani S. Development of Java Tea based Functional Drink: Scale-up Formula Optimization based on the Sensory and Antioxidant Properties. J App Pharm Sci, 2018; 8(09): 055-060. 